\title{
ROLA IDEOLOGICZNYCH BARIER W TRANSFORMACJI SYSTEMOWEJ
}

\begin{abstract}
Streszczenie
Celem tekstu jest opisanie roli ideologii w kształtowaniu transformacji oraz wpływie ideologii na hamowanie procesów przemian. Wagę czynników ideologicznych podkreślano w literaturze szczególnie w pierwszych kilku latach po transformacji. W artykule postarano się pokazać, że za spowalnianiem procesów transformacji kryją się nie tylko materialne i partykularne interesy, ale także przekonania ideologiczne. Wskazano na to, że negatywny światopogląd na gospodarkę rynkową zasadniczo przyczynia się do zatrzymywania lub cofania transformacji. $Z$ jednej strony pozwala on na rozwój procesu politycznego odwracającego przemiany. Z drugiej zaś sprzyja formowaniu się alternatywnych instytucji społecznych, które zastępują funkcjonowanie gospodarki rynkowej. Dlatego trwałe przeprowadzenie przemiany gospodarczej wymaga trwałej przemiany w myśleniu, a także wykształcenia społecznie akceptowalnych instytucji, które ochronią transformację.
\end{abstract}

Słowa kluczowe: transformacja, kapitalizm, socjalizm, bariery, przemiana społeczna, ideologia, interesy

\section{ROLE OF IDEOLOGICAL BARRIERS IN ECONOMIC TRANSFORMATION}

\section{Summary}

The goal of the paper is to describe the role of ideology in shaping transformation and describe the influence of ideology on inhibiting processes of change. The importance of ideological factors was particularly strongly emphasised in the literature during the first years of transformation. The author attempts to demonstrate that what hinders transformation is not only material interests but also doctrinal factors. The paper sets out to prove that a negative attitude to market economy is capable of stopping or reversing transformation. On the one hand, it allows for the development of political processes which can reverse changes. On the other hand, it allows for creating alternative social institutions which serve as a substitute for the market economy. Therefore, permanent economic change requires a profound change in social thinking, as well as socially acceptable institutions which can secure the transformation process.

Key words: transformation, capitalism, socialism, barriers, social change, ideology, group interests

DOI: $10.15290 /$ ose.2015.01.73.07

${ }_{1}$ Dr Mateusz Machaj - Instytut Nauk Ekonomicznych, Uniwersytet Wrockawski; e-mail: m.machaj@ prawo.uni.wroc.pl. 


\section{Niemożliwość „dobrej” transformacji}

Najwięcej kontrowersji dotyczących przemiany z gospodarki socjalistycznej na kapitalistyczną rodzi się w wyniku zasadniczego braku porozumienia co do kwestii tego, czym rzeczywiście „transformacja” powinna być. W związku z tym pojawiają się dwa wyzwania. Po pierwsze, transformacja oznacza przede wszystkim przejście z systemu „socjalistycznego” na system „kapitalistyczny” lub przejście z gospodarki „planowej” na gospodarkę „rynkową". Niestety, na tym ogólne rozumienie pojęcia transformacji się kończy. Nie jest bowiem jednoznaczne, co w istocie oznaczają słowa 'kapitalizm' i 'gospodarka rynkowa'. Kraje zachodnie są przykładem różnych pomysłów na to, jak powinna wyglądać gospodarka nieplanowa oraz jaki zakres oraz forma państwowego interwencjonizmu są dopuszczalne.

Po drugie, w przypadku transformacji jest sporny nie tylko cel ostateczny - czyli np. jak duża powinna być rola państwa w gospodarce - ale również proces dojścia do niego, a więc sposób denacjonalizacji autorytarnego aparatu państwowego. Wydaje się, że sensowne mogłoby być potraktowanie projektu socjalistycznego jako pewnego pomysłu, który zbankrutował. W przypadku bankructwa generalnie wiadomo, jak należy postąpić. Należy zmaksymalizować wartość aktywów, całkowitego majątku z jednej strony, a z drugiej dokonać właściwej hierarchizacji interesów wierzycieli. Gdy bankrutuje firma, o rozdziale majątku decydują kontrakty i system prawny regulujący wagę zobowiązań. W przypadku bankructwa systemu, niestety, takie jednoznaczne przesądzenie nie jest możliwe ani z punktu widzenia prawnego, ani z punktu widzenia moralnego (czego na przykład wyraźnym dowodem może być fakt, iż ludzie o zbliżonych ideologicznie poglądach potrafią diametralnie różnić się w kwestii tego, jak należy denacjonalizować). „Boczne niesprawiedliwości” (collateral injustices), [Blacksell, Born, 2002, s. 188] wydają się w takiej sytuacji wręcz nieuniknione i trudno sobie wyobrazić rozwiązanie bliskie ideału.

Ów spór co do natury procesu przemian można by w pewnym sensie postrzegać jako barierę transformacji, skoro nie istnieje konsensus co do tego, jak ta transformacja ma wyglądać w praktyce. Z tego względu, że nie istnieje jednomyślność w kwestii celów i środków, trudno o sprawne przeprowadzenie transformacji. Różnice w poglądach na to zjawisko sprzyjaja głównie status quo, czyli nieuruchamianiu transformacji w jakiejkolwiek formie lub przynajmniej przyczyniają się do jej opóźniania. W artykule tym można przyjąć roboczo i ogólnie, że transformacja oznacza przejście z modelu realnego socjalizmu do demokracji zachodniej z dominacją własności prywatnej w produkcji, istnieniem rynkowych ograniczeń budżetowych i demonopolizacja partii władzy [Kornai, 2000, s. 29].

W tekście przyjęto gospodarkę transformacyjna za swoisty Weberowski typ idealny. Posługując się terminem gospodarki w transformacji, starano się dojść do pewnych uniwersalnych konkluzji niepowiazzanych z konkretnym miejscem i czasem. Nie wiązano nieodłącznie transformacji ze skonkretyzowanymi historycznymi, przykładami transformacyjnymi, choć w szczegółowych przypadkach kilka razy się do nich odwołano. 


\section{Ideologiczny opór}

W dyskursie politycznym jako główna przeszkodę transformacyjna przedstawia się silne grupy interesów. Aspekt ten szczególnie przykuwa uwagę w świetle tego, że grupy interesu zawsze muszą być siłą mniej liczebną od reszty społeczeństwa, w wyniku czego osiagającą korzyści kosztem większości [por. Tłaczała, 2010, s. 190-191]. Bez wątpienia, bezpośrednie gry interesów odgrywają swoją rolę, ale w tym artykule autor chce wskazać przede wszystkim bariery ideologiczne [Appel, 2000, s. 528]. Główną taką barierą w społecznym postrzeganiu gospodarowania jest marksistowska wizja produkcji i jej konsekwencja: bankructwofobia. Marksistowska wizja sprowadza się do postrzegania produkcji przez pryzmat jej materialnego czy wręcz ,inżynieryjnego” charakteru. Marksizm wraz z jego błędnym fundamentem - laborystyczną teorią wartości - przyczynił się do upowszechnienia przekonania, że produkcja oznacza materializację godzin pracy w fizycznym towarze, który przez taki społeczny proces tworzenia uzyskuje swoją wartość. Tymczasem prowadzenie przedsiębiorstwa bynajmniej nie ogranicza się tylko i wyłącznie do stworzenia produktu materialnego. Oprócz tego, musi to być produkt racjonalny, oceniany w kategoriach kalkulacji pieniężnej. Wiążą się z tym wyzwania: właściwego pozyskania zasobów, adekwatnego systemu zarządzania kadrami, aktywami, pozycjonowania produktu, odpowiedniego marketingu i wiele innych aspektów. Dla prowadzenia firmy produkującej komputery nie wystarczy stworzenie fizycznego komputera, choćby i był to komputer bardzo dobry jakościowo. Czasami nawet pod wieloma względami znakomicie zorganizowane przedsiębiorstwo może popełnić jeden strategiczny błąd i przez to zbankrutować. Tak było w przypadku firmy Kodak, która nie zrozumiała kluczowego znaczenia jej najważniejszego wynalazku (aparatu cyfrowego).

Stąd z perspektywy gospodarki rynkowej naiwne wręcz wydaje się np. mówienie o silnym przemyśle produkującym: znakomite komputery, statki, komponenty do maszyn, tkaniny itd. w jakimś kraju postsowieckim. Silny przemysł nie opiera się na dobrym materialnym produkcie, nawet jeśli jest to produkt relatywnie wysokiej jakości (najczęściej i to może być wątpliwe). Silny przemysł opiera się przede wszystkim na opłacalnym i pożąananm produkcie, który zostaje wytworzony na podstawie racjonalnych reguł produkcji. Można wyobrazić sobie stworzenie znakomitego towaru, jednakże pytanie ekonomiczne zawsze brzmi: za jaką cenę? Społeczne zrozumienie znaczenia tego pytania jest dużo większe np. w krajach anglosaskich aniżeli w krajach postsowieckich. Racjonalność ekonomiczna nie sprowadza się tylko do solidnego produktu. Oznacza ona odpowiednio solidny produkt, ale taki, który nie odciaga środków od alternatywnych, ważniejszych zastosowań.

Mit prymatu materialnej produkcji nad jej ekonomicznym charakterem jest o tyle ważny, że może prowadzić do poważnej konsekwencji w postaci bankructwofobii, czyli obawy przed jakimkolwiek bankructwem. Tymczasem z perspektywy rynków globalnych wiele z przedsiębiorstw po transformacji może opłacać się po prostu zamknąc i to bez względu na to, czy przekazać by je inwestorowi zagranicznemu, czy jego pracownikom w ramach akcjonariatu. Nie dlatego, że ich produkt per se jest złej jakości, lecz dlatego, że niekoniecznie da się tymi przedsiębiorstwami sprawnie i rynkowo zarządzać dla ekonomicznego zysku. 
Z bankructwofobią może wiązać się również ideologiczne przekonanie o możliwościach restrukturyzacyjnych - o tym, że państwo będzie w stanie jakoś firmę postawić na nogi i sprzedać ją z dużym zyskiem. W rzeczywistości jest to przekonanie dosyć paradoksalne - wszak transformację przeprowadza się właśnie dlatego, że państwo nie jest w stanie sprawnie zarządzać przedsiębiorstwami. Stąd wiara w restrukturyzacyjne możliwości i jednocześnie w transformację wydaje się niemal sprzeczna - po co bowiem przeprowadzać transformację, jeśli państwo będzie w stanie stworzyć silnie prosperująca i bardzo dobrze zarządzaną firmę?

W konsekwencji wiara w zbawienną moc restrukturyzacji może zmienić się w pełzające przeciaganie reformy i oddalenie od jej rzeczywistego przeprowadzenia. Wraz z marksistowskim przekonaniem o tym, że produkcja ma charakter materialny może to prowadzić do negatywnego ustosunkowania się do procesu rynkowego, w którym priorytetową rolę odgrywa właściwa ocena kosztów alternatywnych każdego procesu produkcji, a przeprowadzenie transformacji zostanie zastąione restrukturyzacja, która skończy się destrukcyjnymi formami przeedsiębiorcoości [Calcagno, Hefner, Dan, 2006, s. 42], czyli swoistą „pogonia za renta”" przybierającą rozmaite, nieproduktywne ekonomicznie formy [Wilkin, 2010, s. 204-6, 212-213].

\section{Konieczność zaistnienia ideologicznej dźwigni}

Każdy system społeczno-gospodarczy wykształca różnego rodzaju zatory, hamujące rozmaite zmiany w każdą stronę. Jednym z nich są, wspomniane wyżej, przekonania ideologiczne. Ich przeciwieństwem sa kontrideologie, które pozwoliłyby na pokonanie uprzedzeń w sytuacji hamowania transformacji lub na utrzymanie w ryzach alternatywnego porządku społecznego $\mathrm{w}$ związku $\mathrm{z}$ wystapieniem transformacyjnego sukcesu. W literaturze socjologicznej pojawiło się w tym miejscu trafne określenie ideologicznej dźwigni (ideological reinforcing mechanism), [Appel, 2000, s. 543]. W przypadku transformacji od gospodarki socjalistycznej do rynkowej chodziłoby o to, aby w społeczeństwie zakiełkowały jakieś idee, których ludzie chcieliby bronić przede wszystkim z własnego przekonania o ich słuszności, a nie tylko z powodu partykularnego interesu. Chodzi zatem o stworzenie czegoś na kształt „biznes klasy” [Kornai, 1991, s. 33] w znacznie szerszym sensie.

Jest to w zasadzie najważniejszy fundament jakiejkolwiek zmiany społeczno-politycznej. Jednym z problemów transformacji w krajach Europy był jej w dużej mierze „zagraniczny” charakter (choć oczywiście zależy to od kraju). Poszczególne społeczeństwa musiały zaczerpnać wiele rozwiązań politycznych, prawnych i biznesowych spoza własnego kręgu kulturowego, ponieważ w istocie w transformacji chodziło o przyjęcie jednego z możliwych modeli demokracji zachodniej. Dla podtrzymania takich zmian najważniejsze jest to, aby społeczność nie traktowała projektu reform jako elementu obcego czy wręcz pasożytniczego, który został narzucony odgórnie przez klasę polityczna. W zasadzie im bardziej transformacja była postrzegana jako plan narzucony przez obcych kulturowo ekspertów, tym szybciej bywała cofnięta lub wręcz nie dochodziła do skutku. Drogą do jej przeprowadzenia i utrzymania jest zbudowanie w społeczeństwie 
przekonania o tym, że gospodarka rynkowa jest czymś immanentnie powiązanym z lokalną kulturą i tradycjami - że nie jest projektem dyktatorskim narzuconym odgórnie i pod przymusem, od którego nie ma żadnego odwrotu. W przeciwnym razie, transformacja stanie się zjawiskiem obcym i nie nastapi jej jakiekolwiek sensowne przyswojenie ${ }^{2}$. Co więcej, może się to skończyć całkowitym odrzuceniem i powrotem do alternatywnych form gospodarki nierynkowej, w której mechanizmy konkurencyjnej wyceny i doboru kompetencyjnego kadr zostaja zastapione formami oligarchiczno-plemiennymi3 ${ }^{3}$. W tej sytuacji najczęściej władze komunistyczne pozostaja przy szerszej faktycznej władzy, utrzymując poprzednie tradycyjne struktury [Walder, 2003, s. 901].

Przykładem może być swoboda prowadzenia działalności gospodarczej według własnego uznania. Społeczeństwa zachodnie charakteryzują się dużym sentymentem do tej wartości nie tylko ze względu na materialny interes i materialne korzyści, które przynosi, ale ideologiczne przekonanie o tym, że jednostka ma niezbywalne prawo do realizacji swoich pomysłów. W społeczeństwach bardziej kolektywistycznych to przekonanie jest dużo słabsze. Znacznie istotniejsza wydaje się odpowiedzialność przed mityczną „,wspólnotą", która w praktyce sprowadza się do państwa autorytarnego, mogacego wedle uznania niszczyć i ingerować w dowolną działalność biznesową (tak jak to ma miejsce na Ukrainie czy w Rosji).

Gospodarka rynkowa opiera się na zasadzie swobody działalności gospodarczej. Jeśli ta zasada ma być obroniona przez społeczeństwo, to nie może być narzucana przez zagraniczną instytucję. W społeczeństwie musi istnieć pewien ideologiczny motor, który sprzyja społecznemu poparciu dla takiej swobody. Może to być sentyment historyczny, może to być jakieś przekonanie religijne albo utarty społeczny zwyczaj. Musi to jednak być coś bardziej konkretnego i namacalnego, co jest w stanie wywołać pozytywne emocje i nawet poruszające skojarzenia. Coś, czego ludzie będą w stanie bronić jako oczywistego i niezbywalnego, czego władzy nie wolno naruszyć ani podważyć.

Prorynkowy sentyment wpisany w społeczne myślenie wraz z przeprowadzaniem procesu transformacji do gospodarki rynkowej staje się dźwignią tegoż procesu. Jego brak natomiast staje się hamulcem zmian prorynkowych i przez to barierą transformacyjna. Dlatego nowy ład potransformacyjny, jeśli ma pozostać stabilny, musi być wzmacniany zmianami ideologicznymi, które go jednocześnie kształtują i konserwują. Pozytywne ideologiczne podejście do gospodarki rynkowej musi zostać na trwale wszczepione w społeczne myślenie. Pewne jest to, że żadna zagraniczna instytucja nie jest w stanie tego dokonać deus ex machina.

\footnotetext{
${ }^{2} \mathrm{Na}$ zagrożenie konstruktywistyczne zwraca również uwagę Tadeusz Kowalik, powołując się na Hayeka [Kowalik, 1996, s. 291]. Jednak w argumentacji krytyce zostaje poddana sama szybkość zmian, a nie przekonanie do nich czy też źródło ich pochodzenia.

${ }^{3}$ Nie sposób nie wspomnieć w tym miejscu o przypadkach analogicznych, nieudanych prób budowania „demokracji” za pomocą ekspansywnej polityki zagranicznej Stanów Zjednoczonych. Przypadek jest bardzo podobny - rząd zachodni próbuje stworzyć w społeczeństwie zupełnie innym kulturowo coś, co jest traktowane jako produkt obcy i niepożądany. Zasadne pozostaje pytanie, czy coś takiego jest w ogóle możliwe do wykonania bez wcześniejszej, głębokiej przemiany społecznej.
} 


\section{Luka instytucjonalna}

Antyrynkowa ideologia wraz z brakiem ideologicznej kontrideologii, która by ją zwalczała, skutkuje pojawieniem się instytucjonalnej luki między nowymi formalnymi a starymi nieformalnymi instytucjami [Zweynert, Goldschmidt, 2005, s. 3]. Tu w istocie leży sedno impotencji i fiaska projektów przymusowej zmiany społecznej, narzucanej przez zagraniczne instytucje. W każdym społeczeństwie można wprowadzić nowoczesny system prawny i konstytucję $z$ poszanowaniem indywidualnych praw obywateli, wraz kodeksem cywilnym, rozszerzającym zakres swobody działalności gospodarczej. Mogłyby to być nowe formalne instytucje, które maja gwarantować istnienie rynkowej, zreformowanej gospodarki. Jednakże przy braku, wspomnianej, ideologicznej dźwigni, powszechnego społecznego przekonania o konieczności istnienia tych instytucji szybko zaczną one być traktowane właśnie jako ciało obce, jako fikcja, która jest całkowicie nieistotna dla bieżącego życia gospodarczego. W wyniku tego, wykształcą się instytucje alternatywne lub też wygrają wcześniej już istniejące instytucje nieformalne, które w praktyce będą decydować o tym, jak kształtuje się życie społeczno-gospodarcze4. Rolę konkurencyjnego rynku weźmie na siebie jakaś nomenklatura, jak to było w latach sowieckich [zob. Brus, Laski, 1989, s. 136 i nast.]. W konsekwencji „niewidzialna ręka” zostanie zastąpiona „ręka grabiącą" lub „pomagająca”" [Frye, Shleifer 1997, s. 355].

Przykładowo w prawie można wpisać nowe regulacje dotyczące spółek handlowych, które precyzuja, że przedsiębiorstwem kieruje zarząd odpowiadający przed akcjonariuszami. Prawo jednak pozostanie martwe, jeśli w społeczeństwie będzie widziane jako zapis fikcyjny, narzucony przez arbitralne zmiany. Zamiast tego o działaniu przedsiębiorstwa mogą dalej decydować rozmaite układy nepotyczno-oligarchiczne, które nie mają związku z autentycznie konkurencyjnym rynkiem finansowym. Nawet jeśli ktoś z teoretycznych właścicieli (akcjonariuszy) będzie próbował wyegzekwować swoje wpływy i podjąć rynkową walkę, to szybko zostanie za pomocą nieformalnych instytucji utemperowany, a jego działanie ograniczone $e^{5}$ W ten sposób bariera ideologiczna, wyrażająca się niechęcią wobec mechanizmu rynkowego, przeobrazi się w skonkretyzowaną barierę instytucjonalna, zaś prawo o swobodzie działalności gospodarczej pozostanie w dużej mierze w sferze teoretycznej i papierowej, podobnie jak w sferze teoretycznej

\footnotetext{
${ }^{4}$ Ma to szczególne znaczenie przy denacjonalizacji przedsiębiorstw. Główna różnica między krajami bałtyckimi a Białorusią w procesie prywatyzacyjnym polegała na tym, że na Białorusi więcej przedsiębiorstw pozostawało pod kontrola państwa [Savchenko, 2002, s. 240-241]. Po pewnym czasie, w wyniku pozostawienia większej państwowej kontroli przedsiębiorstw, priorytetową rolę zamiast (nieistniejącej) nowej klasy biznesowej odgrywała klasa polityczna. W konsekwencji dostarczało to narzędzi egzekwowania nieformalnym, spolityzowanym instytucjom, mimo teoretycznie istniejącej gospodarki rynkowej.

5 Przykładem może być instytucja „oświadczenia woli”, która jest podstawowym narzędziem realizacji swobody umów. Zmuszenie kogoś siłą i przymusem do złożenia podpisu na umowie jest w zasadzie całkowitym podważeniem tego narzędzia. Jednym z bardziej medialnych i spektakularnych (choć ekstremalnych) przykładów jest przypadek oligarchy Olega Derispaskiego, który został publiczne zmuszony przez Władimira Putina do złożenia podpisu na jednym z dokumentów. Abstrahując od samego faktu, że trudno nazwać przypadek Derispaskiego przypadkiem prorynkowego bohatera, to przykład ten dobrze pokazuje, jakie podejście ma się w Rosji do instytucji suwerennego oświadczenia woli.
} 
pozostawały implikacje wiążące się z konstytucją w Polskiej Rzeczypospolitej Ludowej. Nawet teoretyczna „prywatyzacja” może zostać przeprowadzona w taki sposób, że nie zostanie utworzony w pełni wolny rynek kapitałowy i tradycyjny dla kapitalizmu ład korporacyjny [Brada, 1996, s. 84].

\section{Nacjonalizm i centralizacja}

Bez wątpienia, jednym z najbardziej intrygujących aspektów wpływających na możliwą transformację jest nacjonalizm, który de facto jest powszechny w przekonaniach całej klasy politycznej w mniejszej bądź większej formie ${ }^{6}$. Jest to czynnik intrygujacy, ponieważ z jednej strony hamuje możliwą transformację, ale z drugiej był jej absolutnym fundamentem. Scenariusz historyczny został nakreślony w taki sposób, że ruchy społeczne na rzecz obalenia porządku sowieckiego były przesiąknięte ideologia nacjonalistyczną ${ }^{7}$. Porządek socjalistyczny był traktowany jako obcy, narzucony, nieprzyswojony przez kulturę mniejszych narodów. Został siłowo wprowadzony przez obce państwo rosyjskie. Im bardziej ta dychotomia została zarysowana, tym większa niechęć społeczna została zaznaczona w kraju satelickim, a w konsekwencji transformacja mogła przebiegać szybciej. Największe sukcesy transformacja przyniosła w: Czechach, Polsce i krajach nadbałtyckich. Tam też właśnie antyrosyjskie sentymenty były najbardziej żywe i przyczynily się do odcięcia od poprzedniego porządku polityczno-gospodarcze$\mathrm{go}^{8}$.

Koncepcja samostanowienia narodowego przyspieszała transformację. Jednak oznaczała przede wszystkim wyzwolenie spod obcej okupacji. Konsekwentne wprowadzenie gospodarki rynkowej musiałoby prowadzić do tego, żeby w koncepcje nacjonalistyczne zostały wpisane idee nawiązujące do osiagnnięć zachodnich demokracji. Dlatego nacjonalizm stawałby się czynnikiem przyspieszającym, jeśli oprócz koncepcji samostanowienia miałby wpisany w swoja retorykę mit państwa prawnego, mit wolności gospodarczej, mit ograniczeń władzy państwowej itd.

Jednakże niekoniecznie zostało to przez ideologie nacjonalistyczną dostarczone. Przeciwnie, ideologia nacjonalistyczna może także bronić systemu przed transformacja. Natomiast to w rezultacie świadczy o intrygującym charakterze nacjonalizmu. Z jednej strony pozwala wyłączyć się z sowieckiego molocha i projektu socjalistycznego. Z drugiej strony zaś może stawać się barierą w budowaniu gospodarki rynkowej. Zamiast otwierać

\footnotetext{
${ }^{6}$ Nawet partie otwarcie antynarodowe, lewicowe są w rzeczywistości kryptonacjonalistyczne, ponieważ proponują wprowadzanie polityki gospodarczej i społecznej w obszarze danego państwa narodowego. $\mathrm{Na}$ przykład lewicowa partia nie mówi o redystrybucji dochodu dla ogólnej grupy ludzi biednych, lecz zawsze jest to grupa biednych $w$ danym narodzie (i państwie), a nigdy redystrybucja dla najbiedniejszych na globie. Z tego względu widać, że uniwersalną wartością nie jest generalne uporządkowanie problemów dystrybucji, ale zrealizowanie jakiegoś porządku narodowego.

7 Beissinger wskazuje na to, że nie był to ani czynnik marginalny, ani poboczny [Beissinger, 2009, s. 332 i nast.].

8 W Polsce szczególną rolę odegrał również Kościół Katolicki, który w swojej retoryce był nacjonalistyczny (w szczególności, gdy porówna się go do Kościołów w innych krajach).
} 
drogę do urynkowienia może sprzyjać tworzeniu socjalistycznego skansenu, z tym że w wersji bardziej narodowej aniżeli sowieckiej. Wreszcie nacjonalizm w państwie narodowym może służyć silnej centralizacji władzy, ponieważ najczęściej jest on propagowany w stosunku do państwa narodowego jako centralnej instytucji w życiu społecznym. W wyniku tego, będzie najczęściej niechętnie odnosił się do konsekwentnego wprowadzenia zasady subsydiarności: decentralizacji rządów do poziomu zarządzania niższego niż tego z perspektywy stolicy.

\section{Niedemokratyczne instytucje demokracji}

Jednym z czynników utrwalających istnienie określonego demokratycznego porządku gospodarczego jest pula instytucji, które są odseparowane od procesu demokratycznego. W rzeczy samej to, za co są chwalone demokratyczne systemy zachodnie, to za elementy, które są ściśle antydemokratyczne: sąd najwyższy, niezależny bank centralny, konstytucja i jej prawa, poszanowanie praw mniejszości itd. Przeprowadzenie transformacji, a następnie jej utrwalenie, jest możliwe także dzięki takim instytucjom, które nie moga zostać łatwo zniesione w wyborach powszechnych. Brak takich niedemokratycznych blokad związanych z cofnięciem lub zatrzymaniem transformacji może poskutkować jej odwróceniem.

Dobrym przykładem może być prywatyzacja przedsiębiorstwa przez przekazanie go inwestorowi zagranicznemu. W sytuacji gospodarczego czy społecznego kryzysu jedna z populistycznych partii mogłaby odnieść sukces wyborczy i doprowadzić do ponownej nacjonalizacji firmy. W społeczeństwie bardziej zbliżonym do ideału demokracji zachodniej taki krok jest blokowany przez niedemokratyczne elementy, co w istocie decyduje o pozytywach całego demokratycznego systemu. Na drodze do takiego kroku stoją: system prawny, gwarancje konstytucyjne, interpretacje Trybunału, przepisy o prawach nabytych itd. ${ }^{9}$ Podobnie ma się rzecz z istnieniem banku centralnego, którego władze nie moga zostać odwołane przez premiera rządu. W wyniku tego, monetyzacja długu publicznego i zakłócanie przez to procesu rynkowego politycznymi decyzjami zachodzi w dużo mniejszym stopniu. Wprawdzie bank centralny i tak dokonuje ciagłej redystrybucji przez druk pieniądza, ale w rezultacie wyodrębnienia go z rządu i faworyzowania banków komercyjnych jest to proceder, który skutkuje mniejszą inflacją i mniejszą wszechwładzą rządową [Wojtyna, 1998, s. 13] ${ }^{10}$.

\footnotetext{
${ }^{9}$ Choć, jak niektórzy słusznie ostrzegają, sam Sąd Najwyższy (czy Trybunał Konstytucyjny) i tak często przekracza swoje autentyczne kompetencje [Wright, 1968, s. 1]. Mimo wszystko pozostaje w demokracji zachodniej konkurencyjnym ośrodkiem władzy wobec potencjalnego monopolu władzy rządowej, który występował w krajach socjalistycznych.

${ }^{10}$ Warto wspomnieć w tym miejscu badania Jacka Pietruchy [Pietrucha, 2007, s. 122-123], który zakwestionował dla krajów posttransformacyjnych zależność między niską inflacją a niezależnością banków.
} 


\section{Podsumowanie}

Każdy system społeczny musi w ostatecznym rozrachunku opierać się w jakiejś formie na społecznym poparciu. W utrzymaniu zrównoważonego ładu znaczącą rolę odgrywaja zawsze interesy poszczególnych grup. Niemniej nie jest to jedyny czynnik, który na to pozwala. Drugim i niezwykle ważnym są przekonania ideologiczne w społeczeństwie, które manifestują się nie tylko w powszechnych poglądach, lecz również w instytucjach. To właśnie one zasadniczo przyczyniają się do stawiania barier możliwej do przeprowadzenia transformacji. Idee pozostają najpotężniejszym sposobem przeprowadzania przemian społecznych, ponieważ one w dużej mierze o nich decydowały i to często na przekór potężnym, materialnym interesom.

Materialne interesy są wplecione $\mathrm{w}$ formalne i nieformalne instytucje regulujące życie społeczne. W pewnym stopniu zawsze stanowią odbicie wartości i przekonań dominujących w społeczeństwie. Dlatego najtrwalsza przemiana, która może się dokonać, dotyczy przemiany w poglądach.

\section{Literatura}

Appel H. 2000 The Ideological Determinants of Liberal Economic Reform: The Case of Privatization, „World Politics”, vol. 52, no. 4.

Beissinger M. R. 2009 Nationalism and the Collapse of Soviet Communism, „Contemporary European History", 18, 3.

Blacksell M., K. M. Born. 2002 Private Property Restitution: the geographical consequences of official government policies in Central and Eastern Europe, „The Geographical Journal”, vol. 168 , no. 2.

Brada J. C. 1996 Privatization is Transition-Or Is It?, „The Journal of Economics Perspectives", vol. 10, no. 2.

Brus W., Laski K. 1989 From Marx to the Market: Socialism in Search of an Economic System, Clarendon Press, Oxford, New York.

Calcagno P. T., Henfer F., Dan M. 2006 Restructuring Before Privatization-Putting the Cart Before the Horse: A Case Study of the Steel Industry in Romania, „The Quarterly Journal of Austrian Economics", vol. 9, no. 1.

Frye T., Shleifer A. 1997 The Invisible Hand and the Grabbing Hand, „The American Economic Review", vol. 87, no. 2.

Kornai J. 1991 Privatization: The Great Problem of Transition in Eastern Europe, „Bulletin of the American Academy of Arts and Sciences", vol. 44, no. 8.

Kornai J. 2000 What the Change of System From Socialism to Capitalism Does and Does Not Mean, „The Journal of Economic Perspectives”, vol. 14, no. 1.

Kowalik T. 1996 On the Transformation of Post-Communist Societies: The Inefficiency of Primitive Capital Accumulation, „International Political Science Review / Revue internationale de science politique", vol. 17, no. 3 . 
Pietrucha J. 2007 Awersja inflacyjna a niezależność banku centralnego w krajach transformacji systemowej, [w:] Polityka gospodarcza państwa, D. Kopycińska (red.), Katedra Mikroekonomii Uniwersytetu Szczecińskiego, Szczecin.

Savchenko A. 2002 Toward Capitalism or Away from Russia? Early Stage of Post-Soviet Economic Reforms in Belarus and the Baltics, „American Journal of Economics and Sociology", vol. 61, no. 1.

Tłaczała P. 2010 Analiza grup interesu, [w:] Teoria wyboru publicznego. Wstep do ekonomicznej analizy polityki i funkecjonowania sfery publicznej, J. Wilkin (red.), Wydawnictwo Naukowe Scholar, Warszawa.

Walder A. G. 2003 Elite Opportunity in Transitional Economics, „American Sociological Review", vol. 68, no. 6.

Wilkin J. 2010 Pogoń za renta pray pomocy mechanizmów politycznych, [w:] Teoria wyboru publicznego. Wstęp do ekonomicznej analizy polityki i funkecjonowania sfery publicznej, J. Wilkin (red.), Wydawnictwo Naukowe Scholar, Warszawa.

Wojtyna A. 1998 Szkice o niezależności banku centralnego, Wydawnictwo Naukowe PWN, Warszawa.

Wright S. R. 1968 Role of the Supreme Court in a Democratic Society -Judicial Activism or Restraint, „Cornell Law Review”, 54, 1.

Zweynert, J., Goldschmidt N. 2005 The Two Transitions in Central and Eastern Europe and the Relation between Path Dependent and Politically Implemented Institutional Change, „Hamburg Institute of International Economics. Discussion Paper”, 314. 